\title{
THE BEES (APOCRITA: HYMENOPTERA) OF DHAKA CITY, BANGLADESH
}

\author{
Akter, T., S. Akther, S. Sultana, J. A. Jhorna and S. Begum \\ Entomology Laboratory, Department of Zoology, University of Dhaka, Dhaka-1000, Bangladesh
}

\begin{abstract}
A total of 11 bee species belonging to two families Apidae and Megachilidae was identified. The identified species were Apis dorsata, Apis mellifera, Apis cerana, Apis florea, Ceratina binghami, Ceratina nigrolateralis, Xylocopa aestuans, Xylocopa violacea, Xylocopa latipes, Megachile disjuncta and Megachile umbripennis. The species were identified by using standard taxonomic keys. Details of external morphology like head, wing venation, antennal type, physical coloration etc. were used in the keys. The bees were collected from three areas of Dhaka city - Curzon Hall, Ramna Park and Sher-e-Bangla Agricultural University from October 2017 to May 2018. During the study period it was observed that the richness of bee species was found maximum during the month of October (31.01\%) and was more abundant in Curzon Hall and Sher-e-Bangla Agricultural University area than the Ramna park area. The bee A. dorsata was the most abundant (about $36.23 \%$ of the total population) and M. umbripennis was the least abundant (about $1.74 \%$ of the total population) species in the study areas. It was also observed that bee species were more attracted to the yellow flowers specially Cosmos sulphureus and Tecoma stans than the other coloured flowers.
\end{abstract}

Key words: Hymenoptera; Bee species; Taxonomic position; Species richness; Abundance.

\section{INTRODUCTION}

The order Hymenoptera is one of the major panorpoid endopterygotan pterygotes on earth (Peters et al. 2017, Grimaldi and Michael 2005, Aguiar et al. 2013). The taxa of Hymenoptera have been traditionally subdivided into three assemblages, viz. Symphyta, Aculeata and Apocrita, with 27 superfamilies (9 superfamilies in Symphyta and 18 in Apocrita) and 132 families (Rasplus et al. 2010). The Apocrita includes bees, ants and wasps and characterized by a constriction between the first and second abdominal segments called petiole also involving the fusion of the first abdominal segment to the thorax (Dowton et al. 1994, Dowton et al. 2001).

The Symphyta includes the most primitive members of the order Hymenoptera (Rasplus et al 2010). Many species of sawfly have retained their ancestral attributes throughout time, specifically their planteating habits, wing veins and the unmodified abdomen. The absence of the narrow wasp waist distinguishes sawflies from other members of hymenoptera (Goulet and Huber 1993).

The superfamily Apoidea is a major group and it includes about 20,000 species of bees worldwide (Michener 1974). The bees are one of the more diverse groups because of their apicultural use and for mostly effective as pollinating agents (Engel 2001 and 2012, Michener 2000).

Apidae is the largest family in the order Hymenoptera containing at least 5700 species of bees. The modern honey bees are placed in the genus, Apis taxonomically (Winston 1991). In the early $21^{\text {st }}$ century seven species of honey bee are recognized, with a total of 44 subspecies (Engel 1999). Ten extant species, the dwarf, the giant and the cavity nesting honey bees including the imported European honey bee, Apis mellifera, are found in Asia (Lo et al. 2010). Four types of honey bees are mainly found in Bangladesh because large number of bee's plants species are found plenty throughout the country round the year (Moniruzzaman and Rahman 2009). Carpenter bees (species) belong to the genus Xylocopa. The genus includes more than 500 species (Minckley 1998). Chowdhury and Zethner (1971) recorded four carpenter bees from Bangladesh. Another family Megachilidae is the second largest bee family that contains more than 4000 described species worldwide (Michener 2007, Ascher and Pickering 2011). 
Bhuiya and Miyah (1990) reported seven xylocopid and four megachilid bees from Chittagong (Chattogram) in Bangladesh.

Bees provide vital ecosystem service to pollination both in natural and managed eco-systems (Gallai et al. 2009). They are effective agents to control pest insects (Bale et al. 2008, Brodeur and Boivin 2004, Jonsson et al. 2008). Works on bees are inadequate in Bangladesh and the records are scant of areabased study in Dhaka city. The study was undertaken to know the species richness of the bee in some selected areas of the city. In addition, experiments were made to examine the bee activities in the selected area with the available associated plants.

\section{MATERIAL AND METHODS}

The research was conducted from April 2017 to May 2018. The study areas were Curzon hall premises of Dhaka University, Ramna park and Sher-e-Bangla Agricultural University. The bees were collected during daytime (usually between 8 a.m. and 12 p.m.). They were collected twice from each selected area and were captured with a simple hand net by sweeping. Collected bees were brought to the Entomological laboratory of the department of Zoology, University of Dhaka and sorted out. Then they were pinned and placed in first three to four days under soft day light for 20 to 25 minutes to remove excess moisture from their body.

Taxonomic identification keys have been constructed based on wing venation of the bees. The wings were bleached to make the venation distinct for identification and the technique for bleaching was followed according to Borror et al. (1971)

\section{RESULTS AND DISCUSSION}

A total of 345 individuals from 11 bee species under Apidae and Megachilidae family was collected and examined during the study period. The families belonged to the suborder Apocrita under the order Hymenoptera. The identified species have been arranged in a tabular form (Table 1) following the taxonomic work performed by Bashar (2014).

Table 1. Taxonomic arrangement of the identified apocrits (Hymenoptera) at a glance in a tabular form

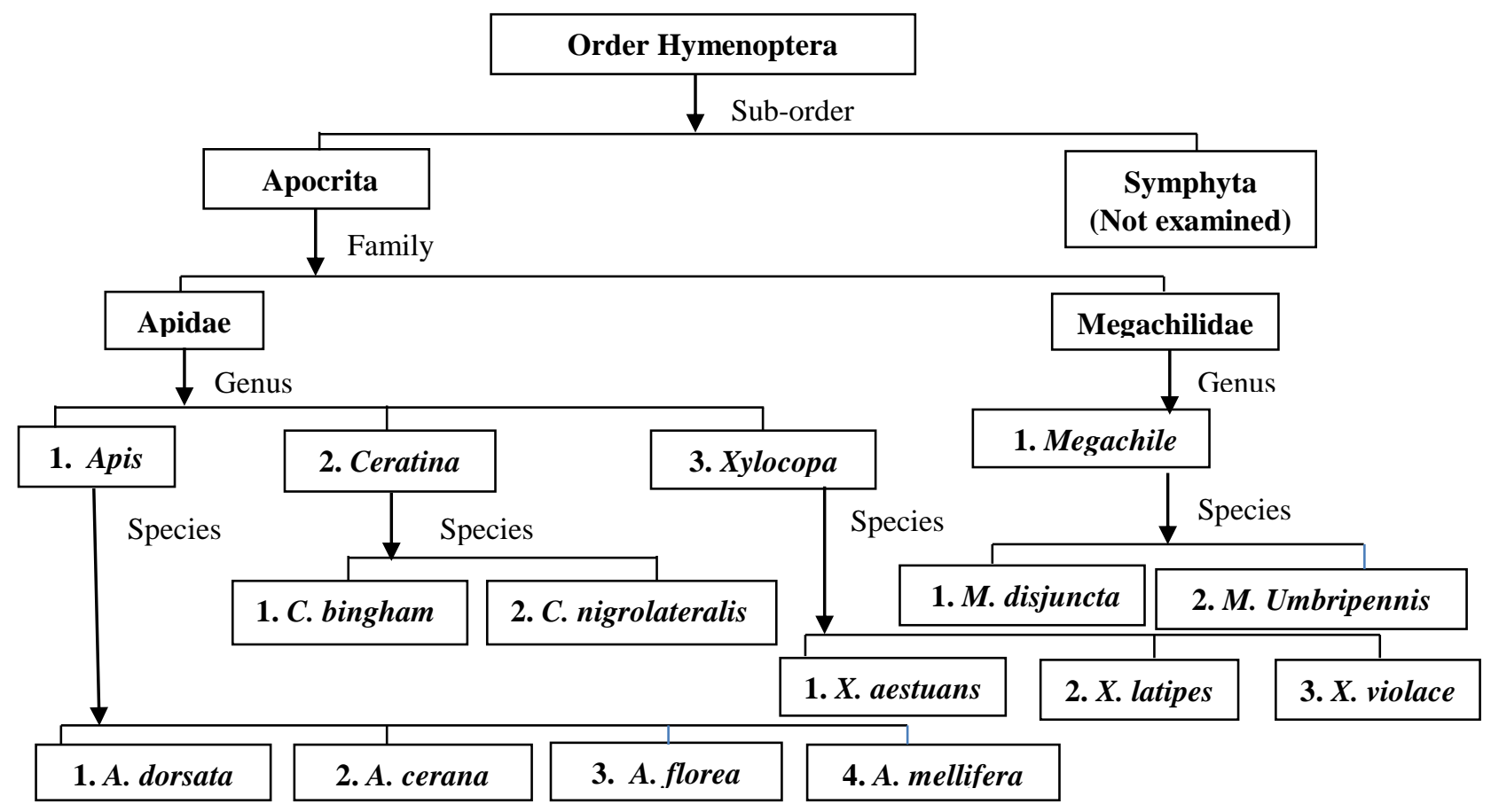




\section{Identification upto species following keys to the sub-order, family, genus and species}

Key to the sub order

1 Absence of constriction between the first and second abdominal segments; trochanter appears two-segmented. Symphyta

$1^{\prime}$ Presence of deep constriction between the first and second abdominal segments; trochanter appears one or two-segmented. Apocrita

Key to the families under the sub order Apocrita

1 Fore wing with 3 sub marginal cells (Fig 1a); pollen carrying structures present on the hind tibia (Fig 1b)

$\mathbf{1}^{\prime} \quad$ Fore wing with 2 sub marginal cells (Fig 1c); pollen-collecting scopa present on the ventral side of abdomen (Fig 1d) Megachilidae

Key to the genera under the family Apidae

1 Absence of spurs on hind tibiae (Fig 1e) Apis

1' Spurs present on hind tibia (Fig 1f) .2

2 Inverted ' $\mathrm{T}$ ' shape clypeus present (Plate g); presence of stigma on fore wing and without distinct break of costal margin (Fig 1h).

Ceratina

2 ' Clypeus is not inverted ' $\mathrm{T}$ ' shape (Plate $\mathrm{i}$ ); absence of stigma on fore wing and with distinct break of costal margin (Fig 1j) Xylocopa

Key to the Species under the genus Apis

1. First three abdominal segments honey-yellow colored and rest black (Fig 1k)......Apis dorsata

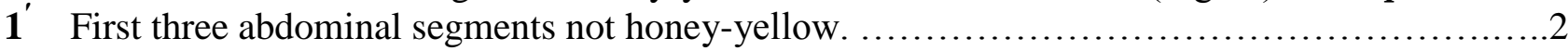

2 Basal five abdominal segments honey-yellow black (Fig 11) .......................Apis cerana

$2^{\prime} \quad$ Basal five abdominal segments not honey-yellow.........................................

3 Basal 2 abdominal segments red (Fig 1m)....................................... Apis florea

3' Basal 2 abdominal segments not red, but Portion of abdomen dark (Fig 1n); Radial vein of hind wing reduced or never more than very small spur (Fig 1o) Apis mellifera

Key to the species under the genus Ceratina

1 Body black with incomplete yellow markings on abdomen (Plate p); Presence of distinctive yellow marking on clypeus and scutellum (Fig 1q-r)... Ceratina nigrolateralis

1' Body metallic greenish (female), shiny without yellow markings on abdomen (Fig 1s); Absence of distinctive yellow marking on clypeus and scutellum Ceratina bingham

Key to the species under the genus Xylocopa

1 Dorsum of thorax covered by dense yellow pubescence except for middle vertical line; usually wings reflection with predominately purple (Fig $1 \mathrm{t}$ )................... Xylocopa aestuans

1 ' Dorsum of thorax not covered by dense yellow pubescence; wings not reflection with predominately purple.

2 Body with black or sooty brown pubescence and thoracic hair black; usually black wing but under sunlight show metallic blue, green and purple color (Fig $1 \mathrm{u})$............ Xylocopa latipes

$\mathbf{2}^{\prime}$ Body with black pubescence; wing with violet reflection; scape blackish and antennal segment black and dark reddish (Fig 1v) Xylocopa violace 
Key to the genus under the family Megachilidae

1. On ventral side of abdomen (female) scopa present (Fig 1d); radial cell present on fore wing and 2 cubital cell present (Fig 1c).

Megachile

Key to the species under the genus Megachile

1. Scopa black in color (Fig $1 \mathrm{w}$ ); $3^{\text {rd }}, 4^{\text {th }}$ and $5^{\text {th }}$ abdominal segment without white fascia............................................................... Megachile disjuncta

$1^{\prime}$ Presence of compressed white fascia on $3^{\text {rd }}, 4^{\text {th }}$ and $5^{\text {th }}$ abdominal segment (Fig 1x) Megachile umbripennis

Eleven bee species were identified from three different areas- Curzon Hall, Ramna Park and Sher-eBangla Agricultural University. Among the identified species nine were under the family Apidae and only two were under the family Megachilidae. Jasmin and Miah (2013) reported 19 bee species under four families from the Bangladesh Forest Research Institute (BFRI) campus, Chittagong. Among these species twelve species belong to Apidae and four to Megachilidae, which contains seven species under three genera viz. Xylocopa, Ceratina and Megachile.

The total numbers of collected bees were 345. The dominant species was Apis dorsata (about $36.23 \%$ of the total population). Whereas, the second highest number was in Apis cerana (15.36\%) and Megachile umbripennis species showed the least abundant group (1.74\%), which was about twenty times lower than the dominant group Apis dorsata (Fig. 2). The highest species richness was found in the month of October and on the basis of collection it was $31.01 \%$ of the total population. But from November the richness gradually started to decrease until February (2.61\%). After February the percentage again started to increase gradually (Fig. 3).

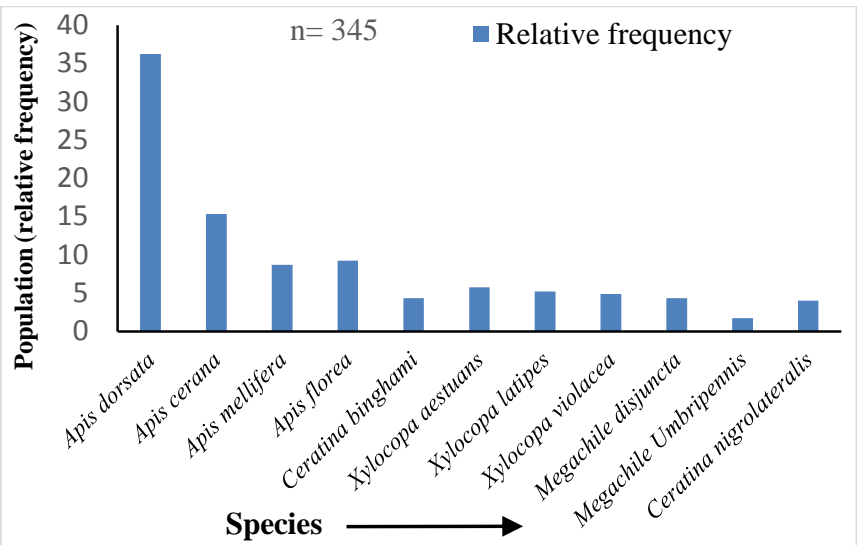

Fig. 2. Relative frequency (\%) of total individuals of each species.

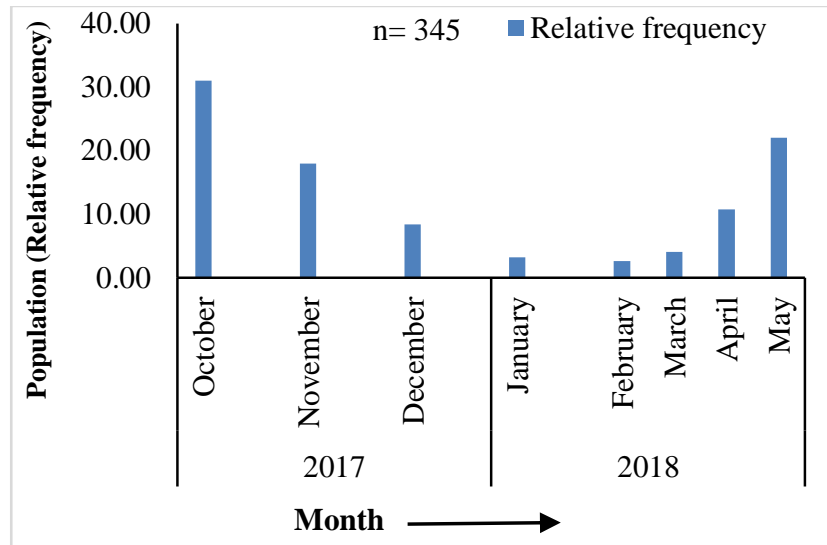

Fig. 3. Relative frequency (\%) of total population per month (collected from October 2017 to May 2018).

The Table 2 shows the list of plants that were attracted to the bees and bees were collected more or less from these plants during the study period. In Curzon Hall area there was a great variety of flowering plants, among which bees were more attracted to yellow flowering plants like Tecoma stans, Cosmos sulphureus, Taraxacum officinale. In Sher-e-Bangla Agricultural University area these yellow flowering plants were absent, but there were a variety of other plants like Corchorus capsularis, Solanum nigrum, Vigana radiata etc. In Ramna park yellow flowering plants were few. Among the study areas, Ramna park is well decorated with tall trees in comparison to Curzon Hall and Sher-e -Bangla Agricultural University. 


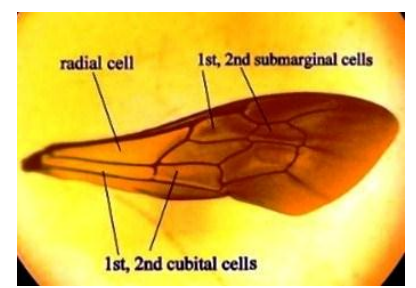

a

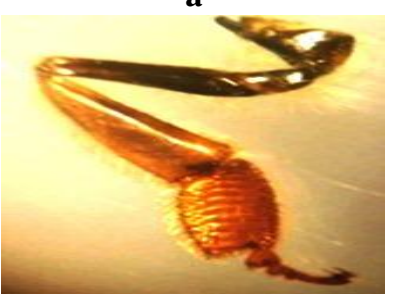

e

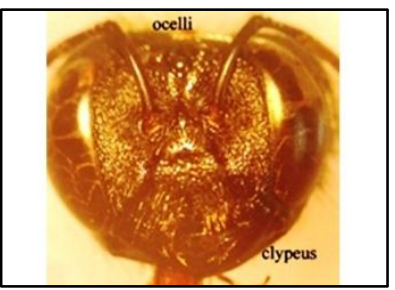

i

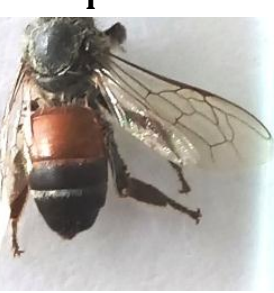

m

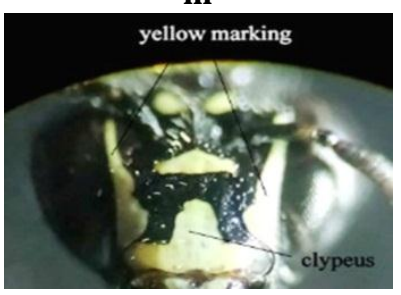

$\mathbf{q}$

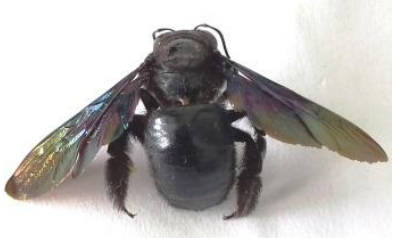

u

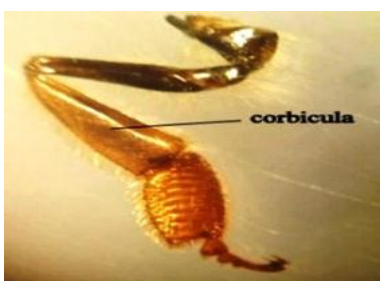

b

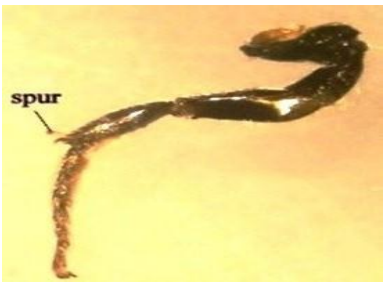

f

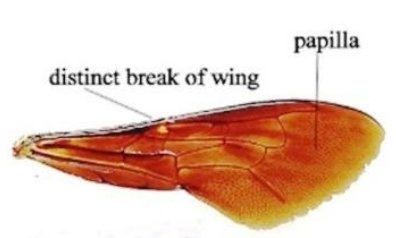

j

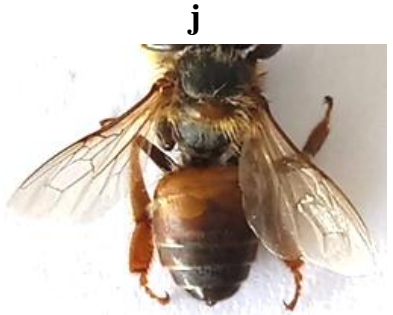

n

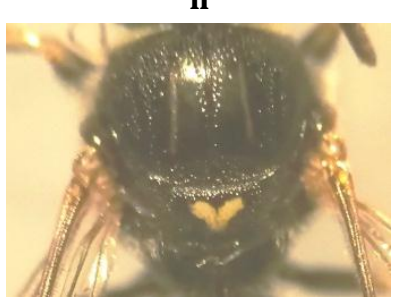

$\mathbf{r}$

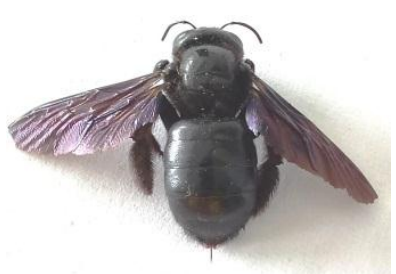

$\mathbf{v}$

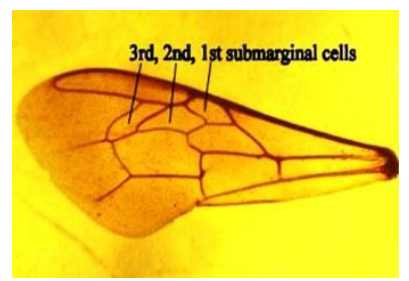

c

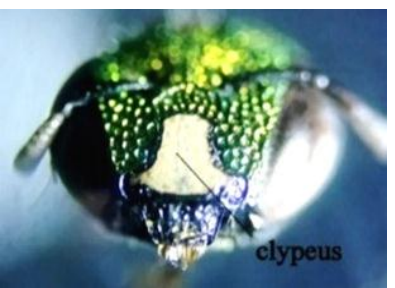

g

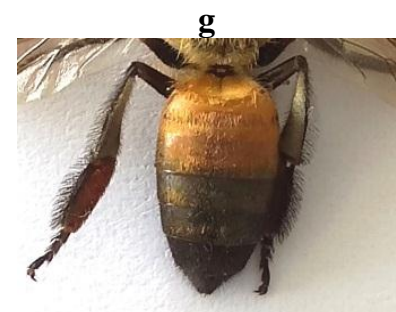

k

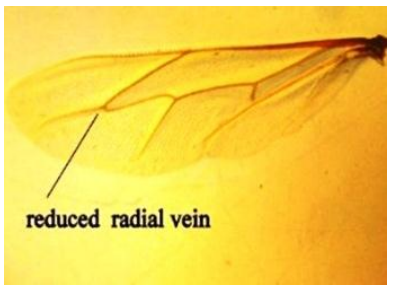

o
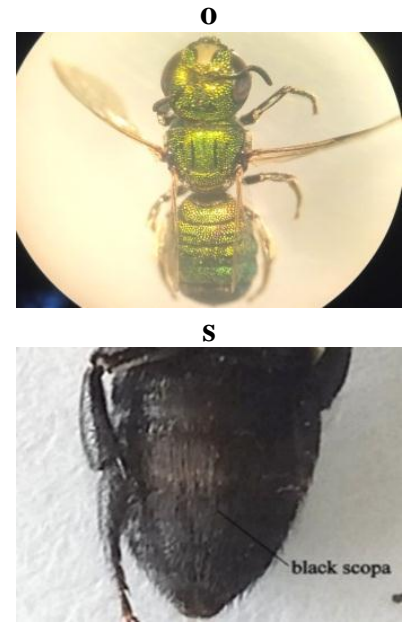

w

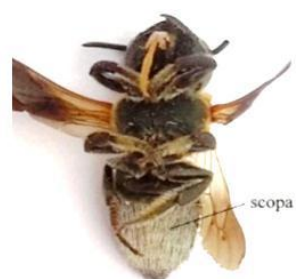

d
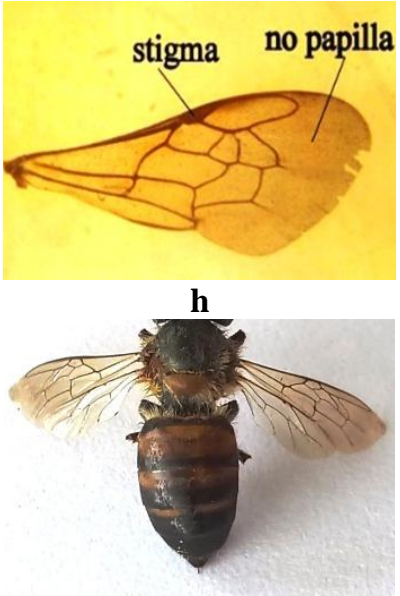

l

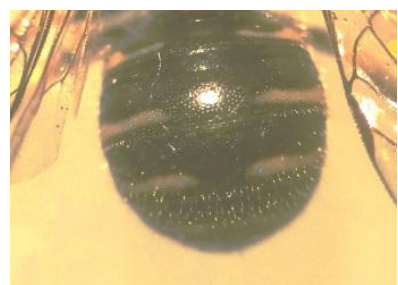

p
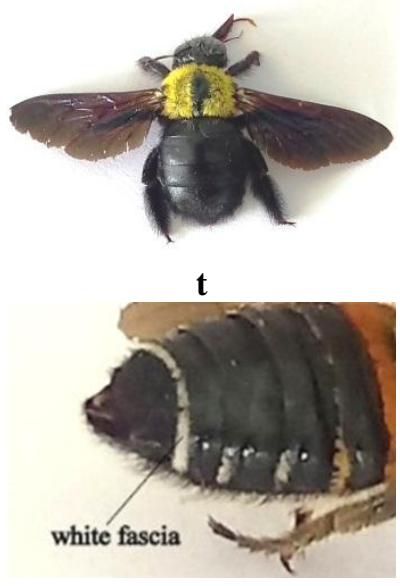

$\mathbf{X}$

Fig 1. Morphological structure of different bees: a. Fore wing of Apis cerana; b. Hind leg of Apis mellifera; c. Fore wing of Megachile disjuncta; d. Ventral side of abdomen of M. umbripennis; e. Hind tibia of A. mellifera; $\mathbf{f}$. Tibia of Ceratina binghami; g. Clypeus of C. binghami; h. Fore wing of C. binghami; i. Head of X. aestuans; j. Fore wing of $X$. aestuans; k. Abdomen of A. dorsata; l. Body part of A. cerana; m. Body parts of A. florea; n. Body parts of A. mellifera; o. Hind wing of A. mellifera; p. Abdomen of C. nigrolateralis; q. Head of C. nigrolateralis; $\mathbf{r}$. Thorax of C. nigrolateralis; $\mathbf{s . ~ C e r a t i n a ~ b i n g h a m i ; ~ t . ~ X y l o c o p a ~ a e s t u a n s ; ~} \mathbf{u}$. Xylocopa latipes; v. Xylocopa violacea; w. Ventral side of abdomen of M. disjuncta; $\mathbf{x}$. Abdomen of M. umbripennis. 
According to Real (1981) bee distribution is affected by plant diversity, canopy cover, plant community composition, nesting suitability, land use and fire history across an open-forest gradient in northwest Indiana, USA; it was also observed that bee abundance is positively related to plant richness and abundance of potential nesting resources, soil characteristics potentially of nesting suitability and negatively related to canopy cover. Individuals belonging to the species Apis dorsata were found on the $54 \%$ (7 out of 13) of the examined plants. On the other hand, the lowest visiting species was Xylocopa aestuans and it was introduced in visiting condition to the 7\% (1 out of 13) of examined plants. It was noticed that the bee species richness was more abundant in Curzon Hall and Sher-e-Bangla Agricultural University than Ramna park. No species of the family Megachilidae was found in Ramna park, and Apis florea and Apis cerana were also absent there. It could be due to the absence of yellow flowering plants. Bees are attracted to yellow and blue flowering plants, but are mostly attracted to yellow flowering plants during foraging (Real 1981). During the study there were a little amount of yellow flowering plants in Ramna park, but in Curzon Hall and Sher-e-Bangla Agricultural University these were enriched with a variety of yellow and other flowering plants. So, the abundance and richness of bee species were found more in that two places.

Table 2. List of plants from which bees were collected.

\begin{tabular}{llllllllllllll}
\hline Species & A & B & C & D & E & F & G & H & I & J & K & L & M \\
\hline Apis dorsata & + & + & + & - & - & - & + & + & + & - & - & - & + \\
Apis Cerana & + & - & - & - & - & - & - & - & + & - & + & - & + \\
Apis mellifera & + & - & - & - & - & - & - & + & - & - & - & - & - \\
Apis florea & - & - & - & - & - & - & - & + & - & - & + & - & - \\
Ceratina binghami & - & - & - & - & - & - & - & - & - & + & - & - & - \\
Ceratina nigrolateralis & - & - & + & - & - & - & - & - & - & + & + & - & - \\
Xylocopa aestuans & - & - & - & - & - & - & - & - & - & - & - & - & + \\
Xylocopa latipes & - & - & - & + & - & + & - & - & - & - & - & - & + \\
Xylocopa violacea & - & - & - & + & - & - & - & - & + & - & + & - & - \\
Megachile disjuncta & - & - & + & - & + & - & - & - & - & - & - & - & - \\
Megachile Umbripennis & - & - & - & - & + & - & - & - & - & - & + & + & - \\
\hline
\end{tabular}

Here, $\mathrm{A}=$ Cosmos sulphureus (Cosmos), $\mathrm{B}=$ Ixora chinensis (Rangan phul), $\mathrm{C}=$ Corchorus capsularis (Pat gach), $\mathrm{D}=$ Solanum nigrum (Begun gach), $\mathrm{E}=$ Abelmoschus esculentus (Dhenrasgach), $\mathrm{F}=$ Mesua ferrea (Nageshar), $\mathrm{G}=$ Turner adiffusa (Damiana), $\mathrm{H}=$ Euphorbia milii (Kontokmukut), $\mathrm{I}=$ Rudbeckia hirta (Daisy), J= Vigana radiate (Moong dhal), K=Brassica nigra (Shorisha), L=Taraxacum officinale (Dandelion) M=Tecoma stans (Chandra probha)

Species diversity is the precondition to maintain the ecosystem services of the nature (Winfree et al. 2018). As the bee species are unique pollinators and play an important role in ecosystem services, the bees were selected as the model organism to observe the present situation of bee diversity in Dhaka city. The area-based study reveals the diversity of bee species, as well as, their abundance and species richness. Further research on bee diversity and on the ecological condition of the city environment will be required to elucidate the actual beneficial effects of bees by studying their population and associated factors influencing on them.

\section{REFERENCES}

Aguiar, A. P., A. R. Deans, M. S. Engel, M. Forshage, J. T. Huber, J. T. Jennings, N. F. Johnson, A. D. Lelej, J. T. Longino, V. Lohrmann, I. Mikó, M. Ohl, C. Rasmussen, A. Taeger and D. S. K. Yu. 2013. Order Hymenoptera. Zootaxa. 3703(10): 51-62. 
Ascher, J. S. and J. Pickering. 2011. Bee Species Guide (Hymenoptera: Apoidea: Anthophila). Discover Life. http://www. discoverlife. org/mp/20q.

Bale, J. S., J. C. Van Lenteren and F. Bigler. 2008. Biological control and sustainable food production. Philos. Trans. R. Soc. Lond. B. Biol. Sci. 363(1492): 761-776.

Bashar, M. A. 2014. Butterflies of Bangladesh: A broad approach for nature lovers. Vol. 1. 1st ed. Biodiversity Conservation Trust Foundation (BCTF) Publications, Dhaka-1000. 515 pp.

Bhuiya, B. A. and M. I. Miah. 1990. A preliminary report on the bees (Hymenoptera: Apoidea) of Chittagong with brief biological notes. Chittagong Univ. Stud. Part II, Sci. 14(2): 125-135.

Borror, D. J., and D. M. Delong. 1971. An introduction to the study of insects. 3rd ed. New York, USA, Holt, Rinehart and Winston, $812 \mathrm{pp}$.

Brodeur, J. and G. Boivin. 2004. Functional ecology of immature parasitoids. Ann. Rev. Entomol. 49: 27-49.

Chowdhury, J. H. and O. Zethner. 1971. An interim result obtained in Forest Section from July 1969 to August 1971. Forestdale News. 4(1): 49-60. 2240-2241

Dowton, M. and A. D. Austin. 1994. Molecular phylogeny of the insect order Hymenoptera: Apocritan relationships. Proc. Natl. Acad. Sci. 91(21): 9911-9915.

Dowton, M. and A. D. Austin. 2001. Simultaneous analysis of 16S, 28S, COI and morphology in the Hymenoptera: Apocrita-evolutionary transitions among parasitic wasps. Biol. J. Linnean Soc. 74(1): 87-111.

Engel, M. S. 2012. The Honey Bees of Indonesia (Hymenoptera: Apidae). Treubia. 39: 41-49.

Engel, M. S. 2001. The Honey Bees of Thailand (Hymenoptera: Apidae). Nat. Hist. Bull. Siam Soc. 49: 113-116.

Engel, M. S. 1999. The taxonomy of recent and fossil honey bees (Hymenoptera: Apidae; Apis). J. Hymenoptera Res. 8(2):165-196.

Gallai, N., J. M. Salles, J. Settele and B. E. Vaissiere. 2009. Economic valuation of the vulnerability of world agriculture confronted with pollinator decline. Ecol. Econ. 68: 810-821.

Goulet, H and J. T. Hurber. 1993. Hymenoptera of the world: An identification guide to families. Agriculture Canada, Ottawa, Ontario. 680 pp.

Grimaldi, D. and M. S. Engel. 2005. Evolution of the Insects. Cambridge University Press, New York. $755 \mathrm{pp}$.

Jasmin, R. and M. I. Miah. 2013. Taxonomy of Bees of Bangladesh Forest Research Institute Campus, Chittagong, Bangladesh. Bangladesh J. Forest Sci. 32(2): 1-14.

Jonsson, M., S. D. Wratten, D. A. Landis, and G. M. Gurr. 2008. Recent advances in conservation biological control of arthropods by arthropods. Biol. control. 45(2): 172-175.

Lo, N., R. S. Gloag, D. L. Anderson and B. P. Oldroyd. 2010. A molecular phylogeny of the genus Apis suggests that the Giant Honey Bee of the Philippines, A. breviligula Maa, and the Plains Honey Bee of southern India, A. indica Fabricius, are valid species. Syst. Entomol. 35: 226-233.

Michener, C. D. 1974. The social behavior of the bees: a comparative study. Vol. 73. Harvard University Press, 404 pp. 
Michener, C. D. 2000. The Bees of the World. 1st ed. The johns Hopkins University press, Baltimore, Maryland, $913 \mathrm{pp}$.

Michener, C. D. 2007. The Bees of the World. 2nd ed. The johns Hopkins University press, Baltimore, Maryland, $972 \mathrm{pp}$.

Minckley, R. L. 1998. "A cladistic analysis and classification of the subgenera and genera of the large carpenter bees, tribe Xylocopini (Hymenoptera: Apidae)". Scientific Papers (Natural History Museum, University of Kansas). 9: 1-47.

Moniruzzaman, M. and M. S. Rahman. 2009. Prospects of beekeeping in Bangladesh. J. Bangladesh Agric. Univ. 7(1): 109-116.

Peters, R. S., L. Krogmann, C. Mayer, A. Donath, S. Gunkel, K. Meusemann, A. Kozlov, L. Podsiadlowski, M. Petersen, R. Lanfear, P. A. Diez, J. Heraty, K. M. Kjer, S. Klopfstein, R. Meier, C. Polidori, Schmitt, T. S. LIU, X. Zhou, T. Wappler, J. Rust, B. Misof and O. Niehuis. 2017. Evolutionary History of the Hymenoptera. Curr. Biol. 27: 1-6.

Rasplus, J. Y., C. Villemant, M. R. Paiva, G. Delvare and A. Roques. 2010. Hymenoptera. BioRisk. 4(2): 669-776.

Real, L. A. 1981. Uncertainty and pollinator-plant interactions: The foraging behavior of bees and wasps on artificial flowers. Ecol. 62(1): 20-26.

Winfree, R., J. R. Reilly, I. Bartomeus, D. P. Cariveau, N. M. Williams and J. Gibbs. 2018. Species turnover promotes the importance of bee diversity for crop pollination at regional scales. Science 359: 791-793.

Winston, M. L. 1991. The biology of the honey bee. Harvard university press. 6 pp. 